Знаходитися в тому парадоксі, про який говорить О. Бассі: «Корисність учителя полягає в тому, аби проявити себе непотрібним (даремним)!» «Корисний», звичайно ж, у контексті тих міркувань, про які говорилося вище, а також для реалізації досить складного ходу дослідження. «Даремний» означає те, що вчитель тримається збоку, аби дозволити тим, хто навчається, оволодіти глибоко й серйозно ситуацією. Інколи доводиться займати становище людини, яка не була почута, але яка, проте, брала участь [Там само, с. 137].

Як показує дослідження, на порядку денному у французькій педагогічній освіті в останньому десятилітті XX - на початку XXI століть постало питання про масове й різноманітне впровадження проблемно-ситуативного підходу. На думку вчених, проблемно-ситуативне навчання може стати серцем системи підготовки вчителів і головною ниткою методів, що раціонально поєднують різні типи дидактичних i педагогічних завдань. За умови дотримання теоретичної бази проблемно-ситуативний підхід може бути представлений різними формами й методами: лекція, в основі якої знаходиться проблемна ситуація, методики «Двійник», «Дзеркало» тощо. Ця зв'язна різноманітність покликана більше породжувати бажання вчителів, які навчаються, бути залученими в педагогічний процес, на відміну від класичного бінома: лекційний курс - практичне заняття або роботи під керівництвом методиста.

Звичайно, у межах однієї статті важко представити особливості розвитку проблемно-ситуативного підходу у Франції в повному обсязі, тому перспективи подальшої розробки вбачаємо у продовженні вивчення змісту, форм і методів проблемно-ситуативного навчання французьких учителів у межах педагогічної освіти.

\title{
Література
}

1. Bassis H. Des maîtres pour une autre école : Former ou transformer? / H. Bassis. Casterman Coll. : Tournai, 1978. - 169 p. 2. Bassis H. Dialogues sur l'Égalité / H. Bassis. Aléas Éditeur, 1990. - 158 p. 3. Bassis H. Je cherche donc j'apprends / H. Bassis. - Paris : Messidor, 1984. - 164 p. 4. Dalongeville A. (Se) former par les situations-problèmes : Des destabilisations constructives / A. Dalongeville, M. Huber. - Lyon: Chronique Sociale, 2000. - 202 p. 5. Dalongeville A. Situations problèmes pour enseigner l'histoire au cycle 3 / A. Dalongeville. - Paris : Hachette, 2000. - 255 p. 6. Démarche SOSIE // Revue Dialogue. 1985. - № 55 [Електронний ресурс]. - Режим доступу : http:/gfen66.infini.fr/gfen66/ IMG/pdf/sosie.pdf 7. Oddone I. Redécouvrir l'expérience ouvrière / I. Oddone. - Éd. sociales, 1981. - 260 p. 8. Brousseau G. Fondement et méthodes de la didactique des Mathématiques / G. Brousseau // Recherches en didactique de Mathématiques. - 1986. Vol. 7. - № 2. - P. 35-115. 9. Huber M. L'histoire indiscipline nouvelle / M. Huber. Paris : Syros, 1996. - $196 \mathrm{p}$.

\section{ВІРТУАЛЬНІ НАВЧАЛЬНІ ПОСІБНИКИ ЯК ЗАСІБ РЕАЛІЗАЦЇ̈ ІНФОРМАЦІЙНО-ДІЯЛЬНІСНОГО ПІДХОДУ В НАВЧАЛЬНОМУ ПРОЦЕСІ}

Царенко О. М. Віртуальні навчальні посібники як засіб реалізації інформаційнодіяльнісного підходу в навчальному процесі.

У статті проведено методичне дослідження загального підходу організації самостійної роботи студентів у вищих навчальних закладах. Сформульовано проблеми неспроможності інформаційного навчання, розглянуто структуру віртуального навчального посібника з загального курсу фізики, показано необхідність формулювання завдань для самостійної роботи, що сприяють професійному 
становленню фахівців.

Ключові слова: самостійна робота студентів, інтелектуальний розвиток, інформаційно-діяльнісний підхід, віртуальний навчальний посібник, самоконтроль засвоєних знань.

Царенко О.Н. Виртуальные учебные пособия как средство реализации информационно-деятельностного подхода в учебном процессе.

В статье проведено методическое исследование общего подхода организации самостоятельной работы студентов в высших учебных заведениях. Сформулировано проблемы несостоятельности информационного обучения, рассмотрена структура виртуального учебного пособия по общему курсу физики, показана необходимость формулирования заданий для самостоятельной работы, способствующие профессиональному становлению специалистов.

Ключевые слова: самостоятельная работа студентов, интеллектуальное развитие, информационно-деятельностный подход, виртуальное учебное пособие, самоконтроль усвоенных знаний.

Tsarenko O. N. Virtual textbooks as a means of implementing information-active approach in the classroom.

In the article the methodical study of the overall approach to the organization of independent work of students in higher education institutions is given. The author formulates the problem of insolvency of information training, considers the structure of the virtual textbook on general physics, states the necessity of formulating Exercises that promote the professional development of staff.

Key words: independent work of students, intellectual development, informationactivity approach, a virtual textbook, self-learned knowledge.

Отримання вищої освіти в різних країнах має свої особливості, але має визначальним створення загального наукового, освітнього й інтелектуального простору. Останній же, з його орієнтацією на самоосвіту, висуває досить високі вимоги до студентів, їх ставлення до навчального процесу, передбачає їхню готовність отримувати знання самостійно $[1 ; 5]$.

Знання, потрібні випускникові вищого навчального закладу (ВН3) у його майбутній професійній діяльності, формуються в курсах фундаментальних i професійно-орієнтованих дисциплін. Однак труднощі, 3 якими стикаються випускники у процесі професійної адаптації, свідчать про недостатність отримуваних знань - більшість випускників не мають узагальнених уявлень про застосування знань і практичного досвіду розв'язання реальних проблем у професійній діяльності [1].

Одна 3 головних причин цього полягає в тому, що студенти, починаючи 3 молодших курсів, вивчаючи основи точних наук, отримують недостатні уявлення про ïх застосування у розв'язанні практичних і виробничо-педагогічних завдань. Тому такі знання часто швидко забуваються і в майбутньому не допомагають випускникам у розв'язанні завдань, що виникають у подальшій професійній діяльності. У свою чергу, неглибокі уявлення про можливе застосування знань i, отже, про необхідність i способи їх самостійного отримання негативно впливають на формування світогляду майбутніх фахівців, здатність оцінювати свої можливості під час розв'язання тих чи інших питань, знижує їхній професіоналізм.

Отже, формування узагальнених уявлень про відповідність знань певним ситуаціям, можливість їх застосування, методологія розв'язання професійних завдань 
має охоплювати зміст усіх навчальних дисциплін, а не тільки спеціальних, i здійснюватися поетапно. Перш за все необхідно знайти оптимальний спосіб викладання точних і прикладних наук з перших курсів, що дозволить перейти від інформаційного навчання, яке зводиться, до подання навчальної інформації викладачем, до освіти, метою якої $є$ не тільки засвоєння знань, а й формування світогляду, розвиток діяльнісних здібностей майбутніх фахівців - до самостійного отримання й застосування знань у професійній діяльності та в житті. Потрібно визначити пріоритетні форми, методи, засоби i критерії якості навчання, які створюють умови задля всебічного розкриття творчого потенціалу особистості майбутнього фахівця.

У європейському освітньому просторі лекційно-семінарська форма навчання давно втратила свою ефективність - практика довела, що майже $50 \%$ навчального часу при цьому витрачається даремно. Тому сучасна педагогіка вимагає, щоб викладач ВНЗ виступав не в ролі поширювача інформації, як це традиційно прийнято, а в ролі консультанта. Це дає значні позитивні зрушення: студенти активно беруть участь у процесі навчання, привчаються мислити самостійно, пропонують свої думки (позиції), вчаться моделювати реальні ситуації тощо.

Метою cтатmi є дослідження дидактичних проблем у сучасному вищому навчальному закладі, які слід реалізовувати задля активізації самостійної роботи студентів під керівництвом викладача. На це орієнтовані всі відомі директиви 3 організації навчального процесу та впровадження індивідуально-орієнтованої системи навчання $[3 ; 4 ; 6]$.

Якщо до середини 80-х років самостійна робота в навчальних планах ВН3 навіть не згадувалася, то починаючи 3 кінця 80-х років і донині навчальними планами на самостійну роботу виділено спеціальний час (в Україні - від $33 \%$ до $66 \%$ навчального часу) $\mathrm{i}$, таким чином, ця форма роботи студентів має особливий статус. Тепер функції викладача не повинні вичерпуватися традиційним поданням навчальної інформації- він повинен стати викладачем-технологом, організатором творчої, самостійної роботи студентів. На основі такої роботи відбувається становлення професійної самостійної діяльності студентів, розвивається самовиховання. Отже, в сучасних умовах кожен викладач повинен долучитися до інтенсивного пошуку теоретичних передумов і практичних розробок 3 організації самостійної роботи студентів у ВНЗ. Як показує науково-педагогічний досвід, такі проблеми гостро виявляються під час організації та реалізації навчального процесу 3 курсів фундаментальних дисциплін.

У педагогіці вищої школи самостійна робота студентів розглядається як специфічна форма навчальної діяльності, і такою, що $є$ наслідком спеціально організованої навчальної діяльності студентів [3]. Уважаємо, що таке визначення недостатньо чітке, оскільки самостійна робота повинна розглядатися як складник навчальної діяльності, яка має відповідну мотивацію, мету, предмет, умови та механізм реалізації. Коли самостійна робота студента займає значну питому вагу його підготовки як фахівця, він може навчитися, в умовах певної ії організації, аналізувати проблемні ситуації, виявляти проблему, формулювати завдання, знаходити й обгрунтовувати алгоритм ії розв'язання, реалізовувати його, перевіряти правильність отриманих результатів.

Нині організація навчального процесу у ВНЗ націлена на скорочення обов'язкових аудиторних занять, має на меті розвиток творчих здібностей майбутніх фахівців та посилення їхньої індивідуальної підготовки. Самостійна робота як засіб організації навчання та наукового пізнання студентів повинна виступати в подвійній 
якості: як об'єкт діяльності студента (завдання, яке він повинен виконати) і як форма вияву ним того чи іншого способу діяльності (виконання завдання 3 метою безпосереднього отримання нових або поглиблення наявних предметних знань). Тому самостійну роботу студентів слід організовувати так, щоб у них виникали мотиви, які б спонукали до самостійного поглиблення і розширення отриманих знань, сприяли активізації та розвитку мислення, інтелектуального потенціалу студентів, i як наслідок, - забезпечували б оволодіння професійною діяльністю із застосування знань. При цьому критерієм ефективності створюваних педагогічних умов професійної підготовки є рівень самостійності - інтелектуальної якості особистості, що означає іiі відносну незалежність, рішучість та ініціативність.

За традиційного навчання 3 тією чи іншою ефективністю реалізується по суті інформаційний або інформаційно-рецептивний метод навчання, коли знання студенту передаються в готовому вигляді, робляться вказівки щодо їх застосування в конкретних професійних ситуаціях. Застосовувані при цьому методи активізації мислення достатньо ефективні і покращують параметри знань, але не сприяють інтелектуальному розвитку i формуванню нових інтелектуальних рис, що забезпечують успіх майбутньої професійної діяльності [2]. Пояснити це можна тим, що інтелектуальна структура фахівця формується в ході органічно пов'язаних між собою процесів накопичення і впорядкування знань у певну структуру професійної діяльності, яка сприяє підвищенню швидкості розумових процесів у конкретних проблемних ситуаціях. Важливість орієнтації на категорію інтелекту в даному випадку пов'язана з тим, що саме узагальненим терміном «інтелект» можна позначити здатність студентів до поступової адаптації та до їхньої майбутньої професійної діяльності.

Розвиток і вияв інтелекту можливі тільки в конкретній діяльності, в якій процеси інтелектуального розвитку та навчання застосування знань студентів ВНЗ нерозривно пов'язані і взаємно зумовлені, складаючи їх сутність, а отже створюють єдиний процес підготовки студентів до вміння застосувати знання у професійній діяльності. Зазначимо, що інтелектуальний розвиток звичайно ж впливає на становлення професійної діяльності студентів, а процес самостійного засвоєння знань може стати необхідною і достатньою умовою організації їхньої інтелектуального розвитку на основі професійної спрямованості навчання. Організація самостійної роботи у ВНЗ повинна будуватися з метою реалізації саме такого підходу.

Отже, необхідний цільовий підхід, який орієнтує всі компоненти навчання щодо доцільності формування мислення майбутнього фахівця. Педагогіка вчить, що мислення - це процес сприйняття, збереження, перероблення, створення та використання інформації у професійній діяльності та життєдіяльності. I незважаючи на те, що рівень мислення кожного індивіда залежить від його інтелектуальних можливостей, ми повинні знайти такі інноваційні навчальні методи, прийоми, які б сприяли розвитку мислення майбутнього фахівця.

Уважаємо, що це можна реалізувати з використанням інформаційно-діяльнісного підходу, головною ідеєю якого $є$ організація навчально-професійної діяльності 3 урахуванням необхідності стиснення навчальної інформації в результаті іiі упорядкування [8]. Особливо актуальним на етапі впровадження інформаційнодіяльнісного підходу є розроблення принципово нових підручників, оскільки їм тепер відводиться особливе функціональне призначення. Відомо, що класичні підручники, орієнтовані на середнього студента, а тому обмежують можливості виявлення індивідуальних навчальних інтересів кожного учасника навчально-виховного процесу. Сучасний підручник повинен урахувати нові підходи до організації 
навчального процесу, реалізувати всі його провідні елементи.

Підручники для вищої школи 3 природничо-математичних дисциплін давно застаріли, оскільки за послідовністю викладу матеріалу, його структурою i методичними підходами фактично повторюють шкільні. I це, з одного боку, цілком зрозуміло, оскільки навчальні програми шкільних та вишівських курсів з фізики, хімії, біології відрізняються несуттєво. (Виняток становить обсяг матеріалу і математична компонента). Однак такий підхід авторів нових видань не є виправданим. Адже сучасний підручник для вищої школи, окрім традиційних основних компонентів теоретичного подання матеріалу і питань для контролю знань, - повинен обов'язково містити елементи проблемності, дидактичні матеріали, матеріали для самопідготовки, завдання для самоконтролю тощо.

У зв'язку з цим виникає два питання: якою має бути все ж структура сучасного підручника для студентів вузів і яким чином на перехідному етапі використовувати сучасні? Насправді - це досить складні питання, які потребують грунтовного науковопедагогічного дослідження. Однак однозначно вже на сучасному етапі прогнозувати можна бачити модель підручника майбутнього- це віртуальні підручники (або навчальні посібники) та електронні навчальні комплекси - як універсальні навчальні матеріали для забезпечення аудиторної й самостійної роботи студента.

Нині автором реалізується створення віртуальних навчальних посібників з усіх розділів курсу загальної фізики [7]. Кожен з цих посібників має різну структуру і зберігається як документ HTML, або HTML-Kit. Ці формати досить прості та зручні, не потребують спеціальної підготовки автора, дозволяють трансформувати в них файли Microsoft Word. У документах HTML i HTML-Kit можна зберігати точкові малюнки, фотографії, ауді- і відеофайли, електронні моделі, тестувальні програми тощо. У таких віртуальних навчальних посібниках легко реалізувати принцип від простого - до складного, принцип поступового ускладнення навчального матеріалу i, навпаки, повернення до початкових елементів. При цьому сам студент може вибирати залежно від своєї теоретичної підготовки початковий або середній рівень засвоєння навчального матеріалу, знову ж таки з можливістю посилання до більш високого або навпаки до нижчого рівня. Така структура навчального посібника легко створюється введенням «Гіперпосилань» на нові або незрозумілі терміни i формуванням додаткових Web-сторінок.

Уважаємо доцільним, щоб кожен віртуальний посібник містив алфавітний покажчик основних використаних термінів, що дозволяє швидко повторювати пройдений матеріал. Незаперечним $є$ те, що віртуальний навчальний посібник із природничих дисциплін не може бути повноцінним без демонстрацій (у вигляді відеофайлів) тих чи інших фізичних, хімічних, біологічних явищ. Саме ці елементи віртуальних посібників прислужаться студентам, які не змогли 3 різних причин відвідати лекцію і побачити демонстраційний експеримент «наживу». Віртуальні посібники можуть містити і прості віртуальні досліди, які рекомендується виконати самому студенту. При цьому поглиблюються теоретичні знання, $\epsilon$ можливість підготуватися до майбутніх реальних лабораторних досліджень. Віртуальний посібник має містити програми для самоконтролю засвоєних знань, для чого зручно використовувати широко відомі програми, наприклад, конструктор тестів Let's test або платформу Moodle. Досвід роботи 3 цими програмами показав їх високу надійність як 3 позиції практичного використання, так i 3 позиції збереження інформації. Ці програми дозволяють створювати тести для оцінки рівня досягнень студента 3 кожної теми або підсумкового контролю (на іспиті). За допомогою таких тестів легко визначати рівень підготовки майбутнього фахівця, створювати тести 3 
індивідуальними параметрами, враховуючи різні рівні підготовки студента. Звичайно, тільки шляхом тестування складно виявити рівень знань студента 3 природничоматематичних дисциплін. Тому доцільно поряд 3 використанням тестів, формувати питання для самоперевірки знань, підбирати різнорівневі завдання, наповнювати віртуальні посібники електронними моделями 3 можливістю зміни параметрів розглянутих явищ тощо.

На нашу думку, відповідно до інформаційно-діяльнісного підходу викладач, організовуючи самостійну роботу, повинен не просто подавати навчальну інформацію, а звертати увагу студентів на характерні особливості даної інформації і давати рекомендації із поглиблення знань, організовувати отримання навичок 3 їх застосування. Висвітлену думку легко пояснити на прикладі вивчення і застосування в курсі загальної фізики поняття похідної. Визначення похідної функції - одне 3 основних, базових понять математичного аналізу. Класично вивчення його зводиться до тривіального заучування формулювання та трактування його фізичного змісту, як якоїсь швидкості. За такого підходу, як засвідчує педагогічний досвід, у студентів виникає уявлення про те, що в будь-якому випадку похідна - це «швидкість руху». Однак, це звичайно ж не так. Похідну дійсно можна розглядати як швидкість, але як швидкість зміни функції за ії аргументом. У подібних випадках самостійну роботу студентів корисно збагатити спеціальними завданнями на визначення різних швидкостей відносно різних аргументів (руху, імпульсу, моменту, магнітного потоку тощо). При цьому підвищується рівень знань, глибина розуміння поняття похідної і що найважливіше - формуються необхідні навички практичного використання отриманих знань.

У процесі планування й організації самостійної роботи, окрім таких завдань доцільно пропонувати завдання, які сприяють освоєнню різних методів розв'язування фізичних задач. При цьому можна говорити про отримання необхідного досвіду самостійного пошуку знань, формування узагальнених уявлень про методологію розв'язання професійних завдань як складник методології культури майбутнього педагога взагалі, що характеризується його здатністю до наукового обгрунтування, критичного осмислення і творчого застосування певних концепцій, форм і методів пізнання в курсах фундаментальних дисциплін.

На практичному рівні інформаційно-діяльнісний підхід може бути представлений у вигляді системи теоретичних або практичних завдань, інтегруючих як окремі теми навчальної дисципліни, так і теми різних дисциплін. Прикладом таких завдань можуть служити комплексні завдання для самостійної роботи студентів, в яких від теми до теми взаємопов'язаних курсів навчальних дисциплін відбувається процес безперервного управління діяльністю студентів 3 розв'язання професійних завдань. Це повинен бути процес поступового переходу від специфічних простих алгоритмів, що вивчаються в рамках однієї навчальної дисципліни, до все більш загальних. До складу системи комплексних завдань слід обов'язково внести навчально-професійні завдання, які $є$ засобом формування професійної мотивації, інтелектуального розвитку, формування професійних знань у смисловому i процесуальному аспектах, вміння самостійного пошуку і створення інформації. Якість виконання навчально-професійного завдання розглядається i як індикатор професійної придатності людини, і як засіб професійного самовизначення. Самостійна робота при цьому є складником навчально-професійної діяльності студентів.

Ефективність практичної реалізації інформаційно-діяльнісного підходу в організації самостійної роботи значно підвищується 3 використанням комп'ютерної техніки (розв'язуються проблеми доступу до інформації в бібліотеках, через Internet, 
за допомогою електронних та віртуальних підручників; можливе використання навчальних програм, використання пакетів для розв'язання професійних завдань; самоконтроль і контроль).

Упровадження будь-якої інновації у процесі навчання студентів, як правило, забезпечує позитивний результат, проте на сучасному етапі організації навчального варто здійснити розроблення цілісної технології, яка повинна забезпечити досягнення дидактичних цілей і як наслідок - формування творчої особистості фахівця.

\section{Література}

1. Васюренко О. Вищій освіті - ефективний розвиток / О. Васюренко// Вища школа. - 2001. - № 1. - С. 83-90. 2. Максимов О. Системний підхід до вивчення дисциплін вищої школи / О. Максимов // Рідна школа. - 2006. - № 1. - С. 17-19. 3. Про проведення педагогічного експерименту 3 кредитно-модульної системи організації навчального процесу. - Наказ МОН України № 48 від 23.01.2004 р. 4. Сазонов Б. А. Индивидуально-ориентированная организация учебного процесса как условие модернизации высшего образования / Б. А. Сазонов// Высшее образование в России. - 2011. - № 4. - С. 10-24. 5. Салми Д. Как государства добиваются международной конкурентоспособности университетов: уроки для России / Д. Салми, И. Д. Фрумин // Вопросы образования. - 2013 № 1. - С. 25-68. 6. Формы организации учебного процесса [Електронний pecypc] - Режим доступу: http://www.ict.edu.ru/ft/003625/2.html/ 7. Царенко О. М. Механіка: віртуальний курс лекцій [Електронний ресурс] - Режим доступу: http://wiki.kspu.kr.ua/index.php/. 8. Larionova G. Information-activities point of view as the possible basis of higher mathematics/ 2-d International conference on the teachingof mathematics (at the undergraduate level). University of Crete. 1-6 July 2002. Hersonissos. Crete. Greece.

УДК 378.026:744

Людмила Цвіркун

\section{ДИДАКТИЧНІ ПІДХОДИ ТА ПРИНЦИПИ ФОРМУВАННЯ ПРОЕКТНО- КОНСТРУКТОРСЬКОЇ КОМПЕТЕНТНОСТІ У ПРОЦЕСІ ВИВЧЕННЯ ГРАФІЧНИХ ДИСЦИПЛІН}

Цвіркун Л. О. Дидактичні підходи та принципи формування проектноконструкторської компетентності у процесі вивчення графічних дисциплін.

У статті запропоновано дидактичні підходи та принципи, які сприятимуть успішному формуванню проектно-конструкторської компетентності у процесі вивчення графічних дисциплін; зазначено, що комплексне застосування компетентнісного, системного та особистісно зорієнтованого підходів забезпечить не лише засвоєння практичного та теоретичного матеріалу, а й активізує інтелектуальний та вольовий потенціал майбутнього інженера. Автор акцентує увагу на тому, що єдність загальнодидактичних та специфічних принципів сприятиме розвитку особистості та їі подальшому професійному становленню.

Ключові слова: інженер, графічні дисципліни, дидактичні підходи, дидактичні принципи, проектно-конструкторська компетентність.

Цвиркун Л. О. Дидактические подходы и принципы формирования проектноконструкторской компетентности в процессе изучения графических дисциплин.

В статье предложены дидактические подходы и принципы, способствующие успешному формированию проектно-конструкторской компетентности в процессе 